\title{
OVERVIEW OF CONTRACTUAL OBLIGATIONS OF THE KNOW-HOW LICENSOR UNDER THE MACEDONIAN LAW OF OBLIGATIONS
}

\begin{abstract}
The aim of this paper is to provide a comprehensive analysis of a part of contractual obligations of the licensor of know-how and their regulation in the Macedonian legislation. Special emphasis will be placed on two obligations that contracting parties inevitably incorporate into their agreement: the licensor's obligation to transfer the know-how and to give the necessary instructions and information for its successful utilization, and the licensor's obligation to guarantee the material and legal properties of know-how. Thus, this paper is divided into two systematic sections, focusing on each of these obligations respectively and examining the solutions contained in the Macedonian Obligation Relations Act that are applicable in the regulation of these contractual obligations.
\end{abstract}

Key words: know-how, know-how license agreement, obligation to transfer know-how, guarantee of material properties, guarantee of results, technical assistance, liability for eviction.

\section{Introduction}

In order to provide an overview of obligations of the licensor of know-how and their regulation in the Macedonian Obligation Relations Act (ORA), ${ }^{1}$ we must at first address the terms "license" and "license agreement". Generally, a license is an authorization to use. The verb "license" means the act of giving permission to use, while the noun "license" refers to the document memorializing that permission. A license is granted by one party (licensor) to another party (licensee) as an element of the parties' agreement. A licensor my grant a license under all types of intellectual property law in order to authorize a copyright use (such as

*suzana.nashkova@gmail.com

1 Закон за облигационите односи (Law on Obligations). Службен Весник на РM, бр. 18/01, 4/02, 84/08 и 161/09; [hereinafter: Obligation Relations Act (ORA) 
copyright software), patent use (manufacturing an invention), or trade secret use (a secret formula) (Epstein, 1991:§10.01), or in order to grant permission to a licensee to use its secret knowledge and experience. This agreement is known in the legal theory as a know-how license agreement. Based on the aforementioned acknowledgment, we could define the know-how license agreement as an agreement where one of the contractual parties - the licensor of the know-how ${ }^{2}$ is obligated to transfer a specific knowledge and experience in the field of technology, as well as other business and financial knowledge and experiences, to the other party - the licensee of know-how ${ }^{3}$ who is in return obliged to pay the agreed compensation for the transferred knowledge and experience, and to keep them secret under the principle of confidentiality of trade secrets (Lepotić, 2000:377). The Macedonian Obligation Relations Act (ORA) provides a general definition of license agreement, which also includes a possibility for know-how to be a subject of license agreement. Namely, the ORA states that: "By a licensing agreement, a licensor shall assume the obligation to assign to a licensee, entirely or partially, the right of use (franchise) of an invention, technical know-how and experience, trade-mark, sample or model, while the licensee shall assume the obligation to pay a specified fee in return" (art.750:§1).

The content of the know-how license agreement encompasses the rights and obligations of the contracting parties derived from the concluded license agreement. According to the principle of party autonomy of will, which this agreement is based on, the parties are free to arrange their rights and obligations in accordance with the purpose of the agreement. However, this freedom of the contracting parties to freely arrange their contractual relations cannot be understood in absolute terms. Namely, when drafting the contract provisions, the parties should take into consideration the legal and constitutional limitations that apply to this type of agreement. Moreover, the parties should pay special attention to analysis of the legal norms of the International Law applicable to contractual relations with foreign element in case when a know-how agreement contains such element. Also, when it comes to the know-how license agreement, the parties must pay attention to the norms of Competition Law, which by their nature are of imperative character, so that the agreement clauses should not interfere with them. Additionally, when drafting the agreement the parties should base their provisions on: the principle of good faith, the principle of good business practices (bona fides), the principle of prohibition of abuse of rights, etc.

Upon the analysis of the comparative legal theory and contractual practice, it may be concluded that almost all legal systems list the following obligations of the know-how licensor: the obligation to transfer the know-how; the obligation

2 Hereinafter: licensor

3 Hereinafter: licensee 
to guarantee the substantive and legal properties of the know-how that is subject to transfer; the obligation to protect know-how from third parties; the obligation to maintain the secrecy of know-how; the obligation to grant exclusive license for know-how; etc. In this paper, we will examine some of the obligations of the licensor that are explicitly prescribed in the Macedonian Obligation Relations Act, including: the licensor's obligation to transfer the know-how and give the necessary instructions and information for its successful utilization, and the licensor's obligation to guarantee the properties of the know-how that is subject to agreement.

\section{Licensor's obligation to transfer the know-how and give the necessary instructions and information for its successful utilization}

The purpose of every know-how license agreement is to enable exploitation of the know-how. In order to achieve this objective, i.e. in order to ensure that the licensee may exercise his/her rights, the know-how that is subject to the parties' agreement must first be transferred. Therefore, the transfer of the know-how is a fundamental obligation of the know-how licensor. The Macedonian Obligation Relations Act (ORA) expressly regulates this obligation by stipulating that: "A licensor shall be obliged to deliver to a licensee the subject of the license within the designated time limit" (Art. 747:\$1). In legal theory, there are dilemmas concerning the manner of enabling the transfer of the know-how, but it is usually performed as a combination of the following three methods: the obligation to deliver the technical documentation and other technical means, training of the licensee's staff, and providing technical assistance. It should be noted that the staff training can sometimes be considered as technical assistance in a broader sense.

\subsection{Delivery of the technical documentation and other technical means}

Generally, the term "technical documentation" means all written documents containing technical information relevant to the specific know-how. It is practical and recommendable that the agreement includes a technical documentation list along with the clause on the completeness of technical documentation (stipulating that the list includes the entire technical documentation under the agreement). This clause is a contractual provision that obligates the know-how licensor to deliver to the licensee all technical documentation specified in the list and other related documentation necessary for successful exploitation of the know-how. Some know-how license agreements include clauses which obligates the licensor to deliver to the licensee only the technical documentation that the licensor personally considers to be "reasonably necessary" for the successful exploitation of the know-how, or to such an extent that is considered to be "re- 
asonably necessary" (Прица,1981:126). Yet, in the phase of conclusion of the agreement, the know-how licensee is not in a position to know in advance which technical documentation would be sufficient for successful use of the know-how; for this reason, we consider that this obligation should be based on objective criteria rather than on a purely subjective criterion such as the consciousness (bona fides) of the licensor. The former observation is supported by the fact that what seems to be reasonable and necessary in one case may not be sufficient in other case (ibidem). The list of technical documentation may be incorporated in the agreement or attached as an appendix. Given the specific circumstances, it may include all or some of the following: (a) Items: samples, unregistered designs, machines, apparatus, spare parts, tools, special accessories, etc.; (b) Technical documents: formulae, calculations, plans, drawings, etc.; (c) Instructions: notes concerning the design, manufacture or use of the product or process, technical recipes, explanations supplementing a patent, data on the organization of work, requirements in regard to buildings, layout of plant, etc.(UNECE, 1970:§5). The delivery of the technical documentation can be made either on several occasions, according to the dynamics of delivery specified in the agreement, or at once, within the period specified in the agreement or its annex. In terms of delay in the delivery, parties may agree on penalty fees payable in favor of the know-how licensee. The penalties are usually calculated for a period of one week, or for each commenced week of delay, in the amount of $0.5 \%$ or $0.10 \%$ of the knowhow fee (Прица, 1981:128).

The term "other technical means" implies the physical objects/items needed for a better application of the know-how, which can be produced only by the person who possesses the know-how. For example, such means are: molds, tools, CDs and prototypes. One should have in mind that these material/data storages have dual legal status: on the one hand, they are proprietary means and thus they are regulated by Civil Law provisions; on the other hand, they are means that enable the transmission of intellectual information and thus they are regulated by provisions of Intellectual Property Law (Дабовиќ-Анастасовска, 2009:241). The possession of items is one matter and the right to use the information incorporated in those items is another matter, which should be (at least theoretically) separated from the constitutional transfer of the right of use of the subject of license. That distinction is particularly important in determining the license compensation. Namely, in practice, parties sometimes confuse this amount with the sales price of documentation, tools, molds, etc., which may often cause complications in the event of a dispute (ibidem). Concerning the contractual terms and dynamic of delivery, the penalties for delay shall be subject to the same rules which apply to the delivery of technical documentation. 


\subsection{Training of the licensee's staff}

The know-how which is the subject of agreement consists of complex knowledge and experience gained as a result of sophisticated scientific research and development. Therefore, in most cases the transfer of technical documentation is not enough to provide for its successful application. In fact, the nature of the object of agreement imposes obligation on the parties to agree on mandatory exchange of experts, which would train the licensee's staff in methods facilitating a more successful application of the know-how. The provisions governing the staff training involve two basic questions. The first question refers to determining the type of training that should be provided by the know-how licensor; how many people need to be trained; previous qualifications which they should possess; where the training will take place and how long it will last. The second question is related to the issue of regulating the cost of accommodation and traveling costs of the staff participating in training, if it is provided outside the place of their regular business activity (Прица, 1981:129). As a rule, the parties must in advance determine the place where the training will take place. If the training takes place at the licensor's site, whereby he owns more factories or production sites, it is necessary to determine in advance the exact facility (given the licensee's interest that the training takes place at the factory or site that has most modern equipment and technology), as well as the conditions under which the staff would be trained (which should be most similar to the conditions that licensor's staff usually have while performing their daily activities). Additionally, the agreement should in advance specify the number and qualifications of licensee's employees/experts who need to be trained. The agreement shall also specify the length of training for each employee/expert, depending on the qualifications they possess, expressed in a number of days or hours (ibid:130). The agreement should also contain provision related to the compensation of costs in case the licensor fails to provide an adequate training of the licensee's stuff. In that case, the licensee should be entitled to compensation of simple damages (damnum emergens), as well as compensation for lost benefit (lucrum cessans), which the licensee should have gained by the performance of daily activities if the staff were not involved in the training by the licensor.

\subsection{Technical Assistance}

Depending on the subject matter they regulate, the provisions pertaining to technical assistance may be classified into three groups. The first set of provisions includes the provisions which specify the type or manner of providing technical assistance. The specification of the type of technical assistance enables to precisely determine the following issues: whether the assistance will cover supervision of the equipment installation, ongoing assistance during the exercise 
of daily tasks, laboratory services for testing and assessment of the quality of products, etc. (Прица, 1981:134). The second set of provisions is related to questions concerning the status, rights and obligations of persons participating in providing technical assistance. These provisions are necessary given the fact that, in most cases, technical assistance is realized through mutual visits of parties' experts, whose rights and duties should be precisely determined. Finally, the third set of provisions includes those governing costs for the given technical assistance. The compensation of costs for the given technical assistance shall be subject to the same provisions that apply to the compensation of costs for training of the licensee's stuff (ibidem).

The licensor's obligation to transfer the object of agreement (i.e. the know-how) and to provide the necessary instructions and information for its exploitation is explicitly stipulated in the Macedonian Obligation Relations Act (ORA): "The licensor is obliged to transfer the object of the license within the designated time limit" (art.747:§1). Thereby, the ORA stipulates that the licensor is obliged to deliver the technical documentation required for successful exploitation of the subject of the license (art.747:§2). If this provision is interpreted in absolute terms, it can lead to some difficulties in practice. For example, if the licensor of know-how has not been in a position to exploit know-how directly or through third parties prior to the conclusion of the agreement, then it is quite clear that he does not possess additional technical documentation. Therefore, the solution lies in the relative interpretation of this Article, meaning that a licensor is obliged to transfer the subject of the license to the extent that allows the licensee to use it (Дабовиќ-Анастасовска, 2009:246). According to legal theory, the obligation contained in Article 748 of the ORA should also be interpreted in relative terms. The provision states: "A licensor shall be obliged to provide a licensee with all instructions and information necessary for the successful use of the subject of license." The relativity of interpretation is reflected in the fact that licensor will be obliged to give such instructions and information only if he has some. Just like in case involving the obligation to transfer the technical documentation, if a licensor has not previously exploited the subject of the agreement (either directly or indirectly through third parties), then it is quite obvious that he is not in possession of such information (ibidem). When it comes to know-how agreements, especially in case of granting a license for its exploitation, it should be always taken in consideration that it is a business agreement which is expected to bring certain profit for both parties. Therefore, when it comes to provisions related to the delivery of relevant instructions and information, the most efficient instrument may be the clauses pertaining to the calculation of compensation. When the compensation is determined on the basis of results, it is more than apparent that a licensor will be very interested to contribute 
towards the successful exploitation of the know-how by providing more precise instructions and more accurate information to the licensee.

\section{The licensor's obligation to guarantee the properties of the know-how that is subject to agreement}

In bilateral consensual agreements, the contracting parties are liable for the material and legal properties of the subject of agreement. In the know-how license agreement, this responsibility is reflected in the licensor's obligation to guarantee two things: first, that the transferred know-how has the necessary technical characteristics and, second, that its exploitation does not violate the rights of industrial property of third parties (Прица, 1981:134-135). The licensor's obligation to be held liable for the material and legal deficiencies of the transferred know-how derives from the general liability of parties to perform contractual obligations. Relying on the fact that granting a license for transfer of know-how involves some kind of sale, we could say that the liability in these cases does not theoretically differ from the obligation of the seller to guarantee specific properties of goods in general Contract Law. However, considering the intellectual nature of the know-how and the legal nature of the know-how license agreement which differs from the sales agreement, the liability of the know-how licensor cannot be fully equalized with the liability for material and legal deficiencies of goods that are the subject of sales agreement. Hence, the analogy between these provisions may be used only for the purpose of regulating the legal gaps that may arise in case the liability of the know-how licensor is not defined by specific provisions. This obligation is envisaged as an obligation to guarantee the technical and characteristics of the transferred know-how.

\subsection{Guarantee for the technical characteristics}

The licensor of the know-how is obligated to guarantee that the transferred know-how has certain technical characteristics. Nonetheless, he will be liable for technical properties of the know-how that are defined or mentioned in the agreement, but he may be also liable for the properties that the know-how should contain, considering the purpose for which the contract was signed by the know-how licensee if this purpose was known or should have be known by the know-how licensor. The scope of this guarantee covers the guarantee for properness and completeness as well as the guarantee of results, which will be analyzed in the following sections. 


\subsubsection{The guarantee of properness and completeness}

This type of guarantee derives from the purpose of the concluded agreement, which means that it may be implied and does not need to be explicitly defined; but, in practice, it is the know-how licensor that often insist on its incorporation considering the fact that it imposes some limits to this obligation. On the other hand, the guarantee of properness and completeness also covers two types of guarantees: first, it guarantees that there will be no mistakes in the technical documentation and other technical means (corpus mechanicum), and that they are sufficient and suitable for transfer of the specific know- how; second, it guarantees that that there is a common technical feasibility and technical fitness, i.e. technical applicability of the subject of license (Прица, 1981:136).

As for the technical documentation, the know-how licensee may indicate its malfunction or incompleteness at any time during the enforcement of the agreement. Irrespective of the fact whether deficiencies will occur in the phase of design, construction, putting a facility into operation, etc., the licensor is obliged to replace the inadequate documentation with proper one and to compensate the caused damage. If the documentation cannot be replaced or if there is a luck of technical feasibility, the know-how licensee can protect his/her rights by referring on the general contract law principles along with additional contractual restrictions (ibid:141-142).

As noted above, within the scope of this guarantee, the know-how licensor is obliged to guarantee for the common technical feasibility and technical fitness, i.e. technical usability of the subject of license. General technical feasibility is a possibility for technical production of certain items or a possibility to apply a specific procedure in the process of production. According to some authors, this guarantee includes the possibility to use the know-how under usual conditions for production of the specific type of products, or products of quality required for normal use. Special technical feasibility is not presumed automatically and it should be expressly defined. This obligation is foreseen in the Article 749 of the ORA, which states: "A licensor shall guarantee to the licensee the technical feasibility and technical fitness of the subject of license." Unlike the guarantee for technical feasibility, the guarantee for technical fitness, i.e. usability of the subject of license, presumes a guarantee that the specified product or process will be adequate and sufficient for achieving the technical objective defined by the parties when concluding the agreement (Чавдар, 2001:692-693). The technical usability of the know-how can cause certain controversies in practice because sometimes it can be misinterpreted as a guarantee of the know-how licensor of the results that should be achieved by the know-how licensee. The technical feasibility and technical usability are complementary terms, but they 
are not a substitute for each other. It is clear that if the subject of the agreement is technically feasible, but it is not technically usable, then the purpose of the agreement could not be achieved. If the subject of the know-how license agreement is neither technically feasible nor technically unusable, or if it is technically feasible and usable but it produces certain harmful effects, the question arises: How to regulate the responsibility of the know-how licensor? According to the comparative law as well as the domestic legislation, the licensee has several options: first, to request from the licensor to remove the deficiencies within an appropriate period and to claim damages; second, to request a reduction of the compensation proportionally to the damage (actio quanti minoris), or to request termination of the agreement and compensation of damage by the licensor. The compensation is governed by general rules for compensation of damage, whereby the amount will be examined on the merits of each case by determining whether the licensee is entitled to receive compensation in simple damages (damnum emergens) or compensation for lost benefit (lucrum cessans) (Дабовиќ-Анастасовска, 2009:248).

\subsubsection{Guarantee of results}

This type of guarantee obligates the know-how licensor to guarantee to the licensee that he will be able to achieve the desired results in his own production process, upon exerting relevant efforts and under other specific conditions. In addition to the contractual provisions, the following details should be specified: what results should be achieved; the procedure for determining the guaranteed value; and sanctions in case it cannot be achieved. The determination of results that should be achieved is based on certain technical parameters, such as: the quality standards of the final products (hardness, density, firmness, resistance to corrosion, etc.), or the quantity of the final product which may be obtained with the application of production process (considering the consumption of raw materials, energy per unit of production, etc.) (Прица, 1981:142).

The contractual provisions related to the procedure for determining the guaranteed values and, therefore, the liability of the know-how licensor may differ, depending on whether the role of the know-how licensor is limited to being only the equipment supplier, or whether he is both a supplier and a supervisor of the process of equipment installation. Hence, if the guaranteed values were not achieved due to deficiencies in the equipment, the know-how licensor will be obligated to remove them and to compensate the caused damage (Прица, 1981:143). If the licensor appears both as a supplier and a supervisor of the process of equipment installation, in case the guarantied values were not achieved he will be obliged to compensate for the caused damage and pay additional costs for substitution and further adaptation of the equipment. 
Guaranteed results and values are obtained if the guaranteed parameters are continuously achieved and maintained within a specified period, usually six months to one year. If the guaranteed results and values cannot be obtained given the circumstances which are outside the scope of licensor's liability, then he will be released from liability. However, if the guaranteed results cannot be obtained despite the presence of all necessary conditions, it will be considered that there are deficiencies of the know-how. Thus, the licensor will be entitled to remove the deficiencies and to compensate the caused damage. (ibid:144).

\subsection{Guarantee of the legal properties of know-how}

As a kind of contractual liability, liability for legal deficiencies entails imposing an obligation on the responsible party to act upon the request of the other (injured) party and to compensate the caused damage, resulting from the existence of legal deficiencies of the subject of the agreement. The distinctive feature of this kind of liability is that it exists independently from the fault of the responsible party (Marković, 1992:2187). The liability for legal deficiencies of the transferred object or right is called liability for eviction. The term eviction comes from the Latin word "evincere, evictus", which means that the acquirer of the right was defeated in court, i.e. he lost the dispute with a third person who, on the basis of his own ownership right, has taken possession of the right or property (Прица, 1981:147).

The consequences of infringement of the rights of third parties arising from the utilization of the transferred know-how can cause far-reaching consequences for both parties. Therefore, the parties of the agreement have at their disposal various possibilities for regulating this type of guarantee. More precisely, they may include provisions that would limit or exclude the liability of the licensor, obligate the licensor to be liable to certain extent, or obligate him to completely undertake the liability for the infringement of the rights of the third parties (Прица, 1981:145).

\subsubsection{The notion "liability for eviction" and its application in know-how agreements}

When it comes to the agreements governing the transfer of know-how, the term eviction generally refers to the legal harassment of the acquirer of know-how by third parties, whose acts exerted influence on the right of the acquirer of know-how to use the transferred knowledge and experience as a whole or in part (Lepotić, 2000:380). The Macedonian Obligation Relations Act (ORA) regulates the obligation to provide guarantee for the legal deficiencies within the part pertaining to the regulation of the liability of the seller for the legal deficienci- 
es in sales agreements, which can by analogy be applied to the liability of the licensor in the know-how agreements. More precisely, the ORA stipulates that: "A seller shall be liable should the object sold be subjected to a third party's right (infringements) excluding, reducing or restricting a buyer's right, whose existence was not communicated to the buyer, and the buyer did not accept the object subjected to such right" (Art. 496:\$1); in addition, the next paragraph specifies that: "A seller of some other right shall guarantee its existence and lack of legal obstacles for its realization" (ibid:\$2).

The ORA provisions, ${ }^{4}$ establishing in general terms the responsibility of the contracting parties in bilateral (consensual) agreements, are additionally specified for the license agreement in Article 750 of the ORA. According to this Article: "A licensor shall guarantee that the right of use which is the subject of the agreement belongs to him, that there is no lien on it and that it is not restricted in favor of a third person." (ibid§1); "Should the subject of agreement be an exclusive license, the licensor shall guarantee that he has not assigned the right of use to another, either entirely or partially."(ibid\$2); "A licensor shall be bound to protect and defend the right which he has assigned to the licensee against all third parties' requests" (ibid§3). If these provisions are interpreted in relation to Article $501^{5}$ of the ORA and in conjunction with Article 110 of the ORA ${ }^{6}{ }^{6}$ it can be concluded that the licensor's responsibility for the legal deficiencies in the license agreement (and therefore the license for know-how) may be restricted or completely excluded, except if at the time of concluding the agreement the licensor was aware or must have been aware for this deficiencies (Дабовиќ-Анастасовска, 2009:253).

\subsubsection{Forms of liability for eviction}

The liability for eviction is embodied in the following forms of liability: licensor's liability for personal actions, licensor's obligation to protect the licensee from legal disturbance of third parties, and licensor's obligation to return the given amount and compensate the licensee for damage arising from eviction (Прица, 1981:150).

4 See Art.110§2: "A contracting party shall also be liable for legal failure of performance, and shall be bound to protect the other party against third persons' rights and claims, which might exclude or restrict that party's right."

5 See Art. 501§1 LCT: Liability of a seller for legal deficiencies may be limited or entirely excluded by contract.

6 See Art. 110§3 LCT: "These obligations of the transferor shall be accordingly subjected to provisions of the present Law concerning the liability of a seller for substantive and legal failure of performance, unless otherwise specified for a particular case." 


\subsubsection{Liability for personal actions}

This liability implies the obligation of the know-how licensor to enable the licensee to peacefully enjoy the benefits of the acquired rights. Therefore, the licensor should refrain from any action that could upset the licensee or avoid engagement in any legal action that may interfere with the rights and benefits that emerge for the licensee on the basis of the transferred know-how.

\subsubsection{Obligation to protect the licensee}

This obligation implies the duty of the know-how licensor to remove, upon a request of the licensee, the legal disturbance by a third party that could lead to eviction. The ORA explicitly defines this obligation of the licensee as follows: " $A$ licensor shall be bound to protect and defend the right which he has assigned to the licensee against all third parties' requests" (art.750§3). The legal disturbance must include such legal claims that deny the transfer of the right from the licensor to the licensee because the transferred right belongs to the person who submitted the legal claims or because such person possesses some rights that imposes some limitation over the rights of the licensee (Прица, 1981:147-148). In addition, in order to apply the legal mechanism of protection against eviction it is necessary to make sure that such disturbance is of a legal and not of a factual character.

As for the legal claims of third parties, the key issue is in which case they will be justified and in what form. As far as know-how license agreements are concerned, the legal claims of third parties can be justified only if the third party has a patent right on the invention which the know-how is related to, or if he/ she has submitted an application in order to obtain patent protection. These claims could seriously threaten the right of the know-how licensee only if the third party had filed an application for obtaining patent protection before the licensee acquired the know-how and before he provided everything that was necessary for a successful exploitation of the transferred know-how. Yet, the third party is not required to have filed an application for obtaining patent protection before the agreement was signed. The third party could threaten the rights of the licensee even if the application had been filed at the time of concluding the agreement, up to the point when the know-how licensee provides everything necessary for a successful exploitation of the transferred know-how. The signing of the agreement should not be considered as a sufficient ground to assume that the licensee has provided everything necessary for a successful application the transferred know-how (Прица, 1981:148). The kind of contractual clause will be determined on the merits of each case, depending on the specific nature of the know-how. For example, it is presumed that the know-how licensor has provided all that is necessary for successful application of the transferred know-how if 
he has built the necessary facilities, has acquired the necessary equipment, has already trained the staff, etc.(ibidem).

The forms of exercising this protection are different and depend primarily on the type of legal disturbance by the third party. As noted above, they can have a preventive and repressive effect. The preventive effect is expressed through the very existence of contractual provisions governing this obligation. Thus, at the time of negotiation, the licensor will already be aware of this obligation and he should take all necessary actions to prevent the application of the eviction clause due to his negligence or fault. The repressive effect of the obligation to protect against eviction is evident in case of eviction (Lepotić, 2000:383). In such cases, the know-how licensor has several forms of protection at his disposal. Thus, he may give to the licensee all necessary information which would help him refute the demand of the third party. However, if the third party proceeds with the demand before a relevant Court, the licensor may provide assistance by engaging in the dispute in the capacity of an involved party. Furthermore, the licensor may remove the legal disturbance by making an agreement with the third party, which would lead towards terminating the disturbance of the licensee in the future. Finally, the licensor may modify the recipes, formulas and procedures or other components of the know-how; thus, it will no longer affect the rights of third parties (Прица, 1981:150).

\subsection{Obligation to return the given amount and compensate the licensee for damage arising from eviction}

Eviction is a risk which is implied in agreements on the transfer of know-how (Lepotić, 2000:384). The licensor's obligation to return the given amount and compensate the licensee for damage arising from eviction depends on the degree of eviction. In case of complete eviction, due to the right of a third person, the contract is automatically terminated and the licensor shall return the given compensation to the licensee and compensate the damage resulting from the eviction. In case of partial eviction, when the right of the licensee is limited or reduced due to the right of a third party, he could decide whether to ask for termination of the contract or to request a reduction of compensation paid for the transferred know-how. If the licensee decides to demand a termination of the contract due to the reduction or limitation of his right, he shall notify the licensor without any delay (Чавдар, 2001:696). For argumentation on this right of the know-how licensee, we will use the provisions of the ORA governing the right of the buyer to cancel the sale agreement if he was evicted, which by analogy can be applied to the know-how license agreement. Thus, the ORA stipulates: "Should a seller fail to proceed according to buyer's demand and the buyer be deprived of the object, the contract shall be rescinded on the ground of law, and in case of redu- 
cing or restricting buyer's right, he may either repudiate the contract or request a proportionate price reduction" (art.498:\$1). As previously noted, the know-how licensor is liable for eviction regardless of his fault, and he is obliged to compensate the damage caused to the licensee. More precisely, the ORA provides: "The buyer shall in any case be entitled to compensation for loss sustained" (ibid, §3). If the the know-how licensee engaged in a dispute with a third party without notifying the licensor and lost the dispute, he is still entitled to compensation, unless the licensor proves that he had at his disposal the means which could refute the demand of the third party (art.499). According to the ORA, the licensee is also entitled to compensation in case when he acknowledged the obviously justified right of the third party even without the licensor's notification and without engaging in the dispute (ibid, Art.500).

\section{Conclusion}

Considering that the subject matter of the know-how license agreement is knowhow, which is a secret and non-registrable right, this fact largely complicates the process of defining the rights and obligations of the parties involved in this type of license agreement. Given the absence of a special license law (at both international and national level) which would explicitly define and regulate the rights and obligations of the parties arising from license agreements, the parties can rely on the provisions contained in the Law of Obligations, which provides partial but adequate solutions governing the rights and obligations of the license agreement parties.

The Macedonian Obligation Relations Act explicitly defines the obligation of the know-how licensors to transfer the object of license and the obligation to guarantee for the material and legal properties. Based on the analysis provided in this paper, we could conclude that the provisions contained in this Act are sufficient basis for regulation of all aspects of the licensor's obligations. Additionally, in case where some aspects of these obligations could not be regulated on the basis of special provisions of the license agreement, the parties can rely upon the provisions governing the liability of the seller in sales agreements or the liability of the lessor in lease agreements.

Considering the fact that the frequency of international transactions on transferring know-how has significantly increased, we must emphasize the need for a commonly understood and universally recognized provisions that will precisely regulate the rights and obligations of the contracting parties in know-how agreements. We sure hope that the near future holds a promise of a uniform law or convention governing such transactions, and that the Macedonian legislation will be able to promptly implement them. 


\section{References}

Epstein, M. (1991). Drafting license agreements (4th ed.). New York: Aspen Law \& Business

Дабовиќ-Анастасовска, J. (2009) Договор за лиценца - начин за водење бизнис. Скопје: Центар за европско применето право и економија - ЦЕППЕ

Lepotić, B. (2000). Evikcija kod ugovora o "know-how". PravniŽivot, vol.11/2000, 375-385

Marković, S. (1992).Odgovornost za pravne nedostatke izvršenja ugovora o licenci patentiranog pronalaska. Pravni život, vol.11-12/92, 2186-2196

Прица, Р. (1981)Уговор o know-how-y. Београд: Институт друштвених наука Чавдар, К. (2001). Коментар на Законот за облигационите односи. Скопје: Академик

(UNECE) United Nations, Economic Commission for Europe. (1970). Guide for Use in Drawing up Contracts Relating to the International Transfer of Know-How in the Engineering Industry, New York, p.32

Закон за облигационите односи. Службен Весник на РМ, бр. 18/01, 4/02, $84 / 08$ и $161 / 09$

\section{Мр Сузана Нашкова,}

Правни консултант, ЛАРС ДОО. Штип

\section{ПРЕГЛЕД ОБАВЕЗА ДАВАОЦА КNОW-НОW ЛИЦЕНЦЕ СА АСПЕКТА МАКЕДОНСКОГ ЗАКОНА О ОБЛИГАЦИОНИМ ОДНОСИМА}

\section{Резиме}

Овај рад пружа свеобухватну анализу одредаба које се односе на регулисање обавеза даваоца лищенце код уговора о know-how лищенци, са аспекта одредаба садржаних у постојећем Законуо облигационим односима Републике Македоније. У оквиру анализе аутор ставља посебан акценат на две обавезе без чијег испуњења није могуће да дође до настанка важећи уговор о лиценцу генерално, и стога и важећи уговор о лиценци кnоw-how-a. То су: обавеза даваоца лиценце за преношењ $a$ know-how-a и обавеза даваоца лищенце да гарантује материјалне и правне особине преношеног кnоw-how-a. 
Да би дали потпуну слику о природу и обиму обавезапреношења knowhow-a, ова обавеза је анализирана у погледу њених под-облика. Конкретно ова обавеза је разматрана из аспекта начинама на који се пренос врши know-how-a, a то су: предаја техничке документације и других техничких средстава, обука кадрова стицаоца know-how-а и начине пружања техничку помоћ.У другом делу овог рада, извршена је анализа на обавеза о гаранције за својства know-how-а на основу подеља ове одговорности на: одговорност за материјалнихи одговорност за правних карактеристикама know-how-a, тако звана одговорност о евикции. Аутор прави анализу о одговорности о материјалних карактеристикама на бази детаљни приказ њених под облике а то су: гаранција о техничка својства и гаранција резултата. У оквиру овом делу посебан акценат је стављен на анализу одговорности за правне недостатке know-how-a, или одговорности о евикции, у којој аутор указује на конкретне законске одредбе које се односе на регулисање одговорности о евикции у оквиру уговорима о лиценци, док у исто вријеме упућује на одредбама овог Закона које се односе на одговороност о евикции код купопродајног уговора, који се могу применити по аналогији на уговора о лищенци у случајевима када нису довољнепосебне одредбе које се односе на уговоре о лиценци.

Аутор закључује ову анализу са констатацијом да у одсуству посебног лиценцног права (као на међународном, тако и на националном нивоу) који ће прецизније регулисати права и обавезе странака које произилазе из уговора о лиценци know-how-a, стране се могу ослањати на садржане одредбе у Закону о облигационих односа, који предвиђа парцијална, али и адекватна рјешења којима се регулишу права и обавезе за стране уговора о лищенца.Аутор је такође истакнуоконстатацију да са обзиром на чињеницу да фреквенција међународних трансакција преноса «know-how»-а је значајно повећана, потреба за усвајање универзално прихвађених одредбе које ће прецизно регулисати права и обавезе странака ког уговор о лищенцамао»know-how»-a,je више него неопходна. На широј основи усвајање на ваквих прописаћедопринети успешније утврђивање њихових права и обавеза и ће сигурно допринети значајну афирмацију овог уговора.

Кључне речи: кnow-how, уговор о лищенци за know-how; обавеза за пренос knowhow, gаранција о материјалним карактеристикама; гаранција резултата; одговорност за евикцију. 